\author{
Daniel Puciato \\ https://orcid.org/0000-0002-2390-6038 \\ Politechnika Opolska \\ Wydział Wychowania Fizycznego i Fizjoterapii \\ Katedra Turystyki i Rekreacji \\ d.puciato@po.edu.pl
}

\title{
BEHAWIORALNE CZYNNIKI LOKALIZACJI HOTELI - STUDIUM PRZYPADKU OBIEKTÓW Z WOJEWÓDZTWA OPOLSKIEGO
}

\begin{abstract}
Abstrakt: Wybór lokalizacji hotelu jest jedną z kluczowych decyzji gospodarczych. We współczesnej ekonomii coraz częściej kwestionuje się klasyczne czynniki, za podstawy uznając niedoskonałą konkurencję, ograniczoną racjonalność zachowań oraz pozyskiwanie informacji $w$ niepełnym zakresie lub brak umiejętności ich wykorzystania. Znalazło to również odzwierciedlenie w teorii lokalizacji, w ramach której powstał nurt behawioralny. Jego zwolennicy zakładają występowanie pozaekonomicznych, subiektywnych czynników podejmowania decyzji lokalizacyjnych. Wciąż nierozpoznane empirycznie są jednak mieszczące się w tym nurcie przesłanki decydujące o wyborze lokalizacji hoteli. W kontekście tak sformułowanych luk badawczych celem artykułu jest próba identyfikacji behawioralnych czynników lokalizacji hoteli z województwa opolskiego. W pracy wykorzystano cztery główne metody badawcze: przegląd literatury, dokumentacyjną, sondażu diagnostycznego oraz indywidualnych przypadków. Uzyskane wyniki badań potwierdziły istotne znaczenie podejścia behawioralnego w procesie wyboru lokalizacji hoteli niezależnych z województwa opolskiego. Wiąże się to z wyborem lokalizacji wtórnej lub pierwotnej. W tym drugim przypadku, w sytuacji gdy zastosowanie podejścia obiektywnego nie wiązało się z uzyskaniem pewności, że postanowienia są słuszne, czynniki behawioralne odgrywały najważniejszą rolę w procesie decyzyjnym lub stanowiły jego uzupełnienie. Za kluczowe w tym kontekście należy uznać takie czynniki behawioralne, jak: intuicja, naśladownictwo, doświadczenie, miejsce pochodzenia i zamieszkania, przypadek oraz wpływ osób znaczących.
\end{abstract}

Słowa kluczowe: lokalizacja, hotele, czynniki behawioralne, województwo opolskie.

\section{WSTĘP}

Jedną z kluczowych decyzji gospodarczych podejmowanych przez właścicieli jest wybór lokalizacji hotelu. Dobre usytuowanie obiektu oraz odpowiednio dopasowany do niego program usługowy w zasadzie przesądzają o poziomie rentowności, a w konsekwencji - również o perspektywach rozwojowych hotelu. Położenie obiektu jest bowiem ważne nie tylko dla hotelarzy (właścicieli, menedżerów, pracowników hoteli), lecz także dla gości (turystów i przedstawicieli biznesu), a nawet dla kooperantów (biur podróży, dostawców) oraz konkurentów - innych obiektów typu hotelowego (Cheng, 2018; Ju, Zhang, Wang, 2018; Popovic, Stanujkic, Brzakovic, Karabasevic, 2019; Ren, Qiu, Ma, Lin, 2018). Pojęcie lokalizacji działalności gospodarczej definiowane jest jako „umiejscowienie wielkości i rodzaju działalności gospodarczej, obiektu lub zespołu obiektów, w określonym obszarze" (Budner, 2004, s. 22). Można wyróżnić lokalizację ogólną i szczegółową. Pierwsza z nich polega na wyborze określonego kraju, regionu, a następnie jednostki osadniczej (gminy, miejscowości), w której mógłby być usytuowany dany obiekt hotelowy. Lokalizacja szczegółowa wiąże się natomiast z wyborem konkretnego miejsca (działki ziemi), w którym dany obiekt może powstać. W ramach rozpatrywanej kategorii pojęciowej można wyodrębnić także lokalizację pierwotną (czynną) oraz wtórną (bierną). Lokalizacja pierwotna to wybór nowego miejsca działalności dla otwieranego przedsiębiorstwa lub wchodzącego w jego skład obiektu, np. budowa nowego hotelu. Lokalizacja wtórna dotyczy zaś zmiany przeznaczenia obiektów już istniejących, względnie ich rozbudowy, modernizacji lub odtworzenia (Budner, 2004; Godlewska, 2005).

Większość teorii lokalizacyjnych opiera się na kilku założeniach, tj. na: doskonałej konkurencji, pełnej racjonalności, dostępie do informacji i poszukiwaniu przez przedsiębiorstwa optymalnych lokalizacji. Decyzje 
dotyczące usytuowania działalności gospodarczej są podejmowane na podstawie analizy czynników lokalizacji, które Godlewska (2005, s. 35) definiuje jako: „specyficzne cechy poszczególnych miejsc, mające bezpośredni wpływ na kształtowanie się nakładów inwestycyjnych w trakcie budowy obiektu (obiektów) firmy, a także na rentowność netto działalności gospodarczej realizowanej w tych miejscach". Wyniki wcześniejszych badań empirycznych wskazuja że dla hoteli istotne są czynniki lokalizacji, które w sposób umowny można podzielić na trzy grupy: minimalizujące koszty - m.in. dostęp do czynników wytwórczych, głównie ziemi i pracy, oraz koszt ich pozyskania; maksymalizujące przychody - m.in. wielkość popytu i podaży; oraz stymulujące $-\mathrm{m}$.in. zachęty administracyjne, planistyczne czy finansowe, wprowadzane przez władze publiczne (Chou, Hsu, Chen, 2008; Damborsky, Wokoun, 2010; Kowalczyk, 2001; Kundu, Contractor, 1999; Leśniewska-Napierała, Napierała, 2017; Matczak, 2017; Puciato, 2016; Włodarczyk, 2017; Yang, Wong, Wang, 2012; Zhank, Guillet, Gao, 2012; Żakowska, Podhorodecka, 2018). Praktyka gospodarcza dowodzi jednak, że komponentami procesu wyboru są również niepewność i ryzyko, które należy traktować, jako rodzaj kosztów przedsiębiorstwa.

Współczesna teoria ekonomii w dużej mierze podważa jednak klasyczne założenia (Griffin, Tversky, 1992). Obecnie zakłada się raczej niedoskonałą konkurencję, ograniczoną racjonalność zachowań decydentów, niepełny zakres informacji lub brak umiejętności ich wykorzystania. Znalazło to również odzwierciedlenie w teorii lokalizacji, w ramach której powstał nurt behawioralny, oparty na powyższych założeniach. Zwolennicy tej tendencji zakładają występowanie pozaekonomicznych, subiektywnych przesłanek podejmowania decyzji lokalizacyjnych (Kuciński, 2009). W przypadku tej koncepcji główny nacisk kładzie się nie na poszukiwanie metod optymalizacji wyboru lokalizacji, lecz na zrozumienie mechanizmu podejmowania decyzji. Proces wyboru powinien opierać się na wskazaniu lokalizacji zadowalającej, a nie optymalnej. Tego typu ustalenia mają bowiem charakter długookresowy, a ocena poszczególnych miejsc jest dynamiczna i nie musi być cały czas taka sama, np. ze względu na masową emigrację pracowników czy zmianę stopnia zainteresowania turystów określonymi obszarami recepcyjnymi. W tej sytuacji dążenie do optymalizacji decyzji lokalizacyjnej traci sens. Dokonywanie satysfakcjonujących, choć niekoniecznie najlepszych wyborów oraz zastosowanie uproszczonej heurystyki w procesie podejmowania decyzji to kluczowe elementy teorii perspektywy, na której opiera się ekonomia behawioralna (Kahneman, 2011). Dzieje się tak zwłaszcza w sytuacji, gdy jest zbyt wiele informacji, które należy przetworzyć, istnieją elementy niepewności, a czas na powzięcie postanowienia jest ograniczony.
Dotychczasowe badania empiryczne nad behawioralnymi aspektami ustalania lokalizacji dotyczyły wyłącznie przedsiębiorstw przemysłowych i wskazywały na duże znaczenie w tym procesie chociażby wcześniejszych doświadczeń inwestorów zagranicznych (Mariotti, Mutinelli, Piscitello, 2008; Townroe, 1972). Brakuje jednak badań podmiotów rynku turystycznego, w tym hotelowego. Wcześniejsze analizy wskazują wszakże, że perspektywa behawioralna może być istotna, szczególnie w odniesieniu do decyzji o umiejscowieniu małych hoteli niezależnych, o niskim lub średnim standardzie, finansowanych z kapitału krajowego (Puciato, Dziedzic, 2017; Puciato, Gawlik, Goranczewski, 2016; Puciato i in., 2017; Puciato i in., 2019). W kontekście poczynionych uwag celem poznawczym artykułu jest próba identyfikacji behawioralnych czynników lokalizacji hoteli w województwie opolskim.

\section{BEHAWIORALNE ASPEKTY PROCESU WYBORU LOKALIZACJI HOTELI}

Rozwój teorii lokalizacji obiektów hotelowych opierał się dotychczas głównie na tradycyjnych koncepcjach i przebiegał w dwóch kierunkach. W pierwszym przypadku uznawano, że hotele stanowią część gospodarki turystycznej, a teorie lokalizacyjne odnoszą się do turystyki jako całości. Do tego nurtu zaliczane są m.in. koncepcje peryferii Christallera (1964), cyklu życia miejscowości turystycznej Butlera (1980) oraz percepcji przestrzeni turystycznej Miosseca (1977). W ramach drugiego nurtu hotele traktowano natomiast jako odrębne podmioty gospodarcze mające pewne specyficzne cechy, co znalazło odzwierciedlenie m.in. w koncepcjach cyklu rozwoju rynku hotelowego (Hotelling, 1929) oraz globalizacji sektora hotelarskiego (Alexander, Lockwood, 1996). Najważniejsze czynniki lokalizacji wynikające $\mathrm{z}$ wymienionych teorii zestawiono w tab. 1.

W badaniach empirycznych problematykę czynników decydujących o umiejscowieniu hoteli podejmowali zarówno autorzy krajowi, jak i zagraniczni. Kowalczyk (2001) np. za najbardziej dogodne tereny pod lokalizację hoteli w miastach uznał ich części centralne, szlaki i węzły komunikacyjne, centra handlowo-biznesowe, miejsca targowe, brzegi rzek oraz okolice głównych atrakcji turystycznych. Najkorzystniejszymi miejscami usytuowania hoteli poza miastem są natomiast główne szlaki komunikacyjne, przedmieścia dużych miast oraz tereny rekreacyjne, ekspozycyjne i targowe. Puciato i Dziedzic (2017) wykazali, że największy wpływ na wybór lokalizacji hoteli niezależnych miały: dostęp do wykwalifikowanych kadr i gruntów inwestycyjnych, podaż usług turystycznych, nasilenie konkurencji w sektorze oraz 
Tabela 1. Behawioralne czynniki lokalizacji hoteli

\begin{tabular}{|c|c|}
\hline Teorie lokalizacji & Główne czynniki lokalizacji \\
\hline Teoria peryferii & - naturalne walory turystyczne. \\
\hline $\begin{array}{l}\text { Teoria cyklu życia obszaru } \\
\text { recepcyjnego }\end{array}$ & $\begin{array}{l}\text { - popyt turystyczny (wielkość); } \\
\text { - podaż turystyczna (obiekty turystyczne); } \\
\text { - walory turystyczne (naturalne i antropogeniczne); } \\
\text {-innowacyjność obszaru. }\end{array}$ \\
\hline $\begin{array}{l}\text { Teoria percepcji przestrzeni } \\
\text { turystycznej }\end{array}$ & $\begin{array}{l}\text { - popyt turystyczny (ruch turystyczny, preferencje turystów); } \\
\text { - popyt lokalny (liczba i struktura ludności); } \\
\text { - podaż usług turystycznych, kulturalnych, rozrywkowych; } \\
\text { - efekt aglomeracji; } \\
\text { - organizacja dużych imprez; } \\
\text { - rynek turystyczny (wielkość zatrudnienia); } \\
\text { - walory turystyczne; } \\
\text { - cechy środowiska przyrodniczego; } \\
\text { - dostępność komunikacyjna; } \\
\text { - rynek pracy (elastyczność); } \\
\text { - lokalna polityka turystyczna. }\end{array}$ \\
\hline $\begin{array}{l}\text { Teoria cyklu rozwoju rynku } \\
\text { hotelowego }\end{array}$ & $\begin{array}{l}\text { - poziom rozwoju gospodarczego kraju i regionu (wskaźniki makroekonomiczne); } \\
\text { - kondycja ekonomiczna istniejących hoteli (wskaźniki mikroekonomiczne); } \\
\text {-fluktuacja wskaźników makro- i mikroekonomicznych (przebieg i zakres fluktuacji). }\end{array}$ \\
\hline Teoria globalizacji sektora hotelowego & $\begin{array}{l}\text { - globalizacja; } \\
\text { - internacjonalizacja gospodarki; } \\
\text { - poziom rozwoju gospodarczego; } \\
\text { - poziom rentowności branży hotelowej; } \\
\text { - rozwój technologiczny; } \\
\text { - popyt turystyczny; } \\
\text { - podaż turystyczna. }\end{array}$ \\
\hline
\end{tabular}

Źródło: opracowanie własne na podstawie: Alexander, Lockwood (1996); Butler (1980); Christaller (1964); Hotelling (1929); Miossec (1977).

zachęty planistyczno-administracyjne wprowadzane przez władze publiczne. Yang, Wong i Wang (2012) wytypowali najważniejsze czynniki wpływające na wybór lokalizacji hoteli biznesowych, takie jak: osiągalność dla turystów biznesowych (bliskość strumienia popytu), efekt aglomeracji, dostęp do dóbr publicznych i społecznych oraz urbanizacja. Ussi i Wei (2011) natomiast w swoich badaniach nad znaczeniem poszczególnych uwarunkowań umiejscowienia hoteli za najważniejsze z nich - z punktu widzenia inwestora - uznali: poziom rozwoju regionalnego rynku turystycznego, różnorodność walorów turystycznych, stan rozwoju infrastruktury technicznej i społecznej, poziom rozwoju gospodarczego obszaru, jego stabilność polityczną oraz otwartość na turystów.

Dotychczas ukazało się natomiast niewiele prac empirycznych, w których rozpatrywane są pozaekonomiczne czynniki lokalizacji hoteli. Romero-Martinez, Garcia-Muina, Chidlow i Larimo (2019) zauważyli, że $\mathrm{w}$ przypadku sieci hotelowych ważnymi czynnikami lokalizacji mogą być: różnice kulturowe, bariera językowa czy czynniki instytucjonalne. Albert Tóth i Rechnitzer (2018) stwierdzili natomiast w swojej publikacji, że nie wszystkie przesłanki wyboru lokalizacji są obiektywne, gdyż niekiedy otwarcie hotelu następuje wskutek spontanicznej decyzji. W kontekście postawionej przez badaczy tezy w pełni uprawnione i pożądane jest zatem rozpatrywanie czynników lokalizacji o charakterze behawioralnym.

Podejście behawioralne do procesu wyboru umiejscowienia hoteli nakłada konieczność specyfikacji jego podstawowych zasad (Puciato, 2015). Założenia te brzmią następująco:

1. Wybór miejsca usytuowania hotelu nie zawsze jest procesem $\mathrm{w}$ pełni intencjonalnym dla potencjalnego przedsiębiorcy.

2. Otwarcie hotelu może wiązać się zarówno z wyborem lokalizacji pierwotnej, jak i wtórnej.

3. Proces wyboru miejsca na otwarcie hotelu charakteryzuje się dużym stopniem niepewności i ryzyka.

4. Potencjalni inwestorzy nie mają dostępu do pełnej informacji i nie zawsze potrafią właściwie wykorzystać posiadaną wiedzę.

5. Działania inwestorów związane z podejmowaniem decyzji lokalizacyjnych charakteryzują się ograniczoną racjonalnością i niekiedy opierają się na przesłankach subiektywnych, w tym na intuicji.

6. Decyzja lokalizacyjna zwykle podejmowana jest na podstawie analizy czynników minimalizujących koszty, maksymalizujących zyski i stymulacyjnych, a w warunkach niepewności decyzyjnej - również behawioralnych. 
7. W niektórych sytuacjach inwestorzy mogą uzależniać wybór miejsca wyłącznie od czynników behawioralnych.

8. Brak optymalnej lokalizacji nie jest dla przedsiębiorców powodem do zmiany planów inwestycyjnych.

9. Inwestorzy zaliczani do sektora MMŚP, zainteresowani budową hotelu niezależnego, ze względu na wysokie koszty transakcyjne i relatywnie niewielką siłę przetargową ograniczają się niekiedy do wyboru lokalizacji zadowalającej.

Jak już wspominano, umownie można wyróżnić cztery typy czynników lokalizacji, tj.: czynniki minimalizujące koszty, maksymalizujące przychody, stymulacyjne oraz behawioralne. Jest to oczywiście podział uproszczony, gdyż pewne czynniki można zaliczyć do więcej niż jednej grupy. Zaproponowane rodzaje uwarunkowań lokalizacji wydają się trafne, gdyż w celu osiągnięcia najwyższych zysków w hotelach mogą być podejmowane działania zmierzające do maksymalnego zmniejszenia kosztów lub zwiększenia przychodów. Miejsce usytuowania hotelu ma duże znaczenie dla kształtowania się obu tych kategorii finansowych, a w przypadku strony kosztowej odnosi się to nie tylko do etapu użytkowania obiektu hotelowego, lecz również jego projektowania i budowy.

Zważywszy na cele artykułu, najważniejszą grupę przesłanek lokalizacyjnych stanowią czynniki behawioralne, ponieważ to właśnie na nich część inwestorów opiera swoją decyzję lokalizacyjną. Z kolei inwestorzy uwzględniający obiektywne kryteria wyboru lokalizacji również niekiedy mogą brać pod uwagę ten rodzaj czynników, szczególnie w przypadku braku pewności decyzyjnej. Wówczas inwestor wybierający jedno spośród kilku wyselekcjonowanych wcześniej potencjalnych miejsc usytuowania hotelu, mających podobną „wartość lokalizacyjną”, może zacząć analizować przesłanki subiektywne. Zalicza się do nich takie czynniki lokalizacji, jak: intuicja i doświadczenie decydenta, miejsce jego pochodzenia i zamieszkania oraz efekt naśladownictwa (Puciato, 2015). Na marginesie warto zauważyć, że ostatnia z wyszczególnionych przesłanek może mieć niekiedy również podłoże obiektywne. Łączy się to z procesem rozwoju funkcji turystycznej na obszarach recepcyjnych i jest widoczne niekiedy w początkowej fazie napływu inwestycji do określonej miejscowości, czyli w czasie, kiedy każdy przedsiębiorca, który odniesie sukces biznesowy, znajduje swoich naśladowców. Bardzo często dochodzi wówczas do przestrzennej koncentracji inwestycji, co może przynieść określone korzyści ekonomiczne dla znajdujących się tam firm. Wspomniane profity dotyczą przede wszystkim takich kwestii, jak efekt aglomeracji czy dostępność do dóbr publicznych. Korzyści te mogą być związane np. z wysokim stopniem koncentracji przestrzennej podmiotów gospodarczych o określonym profilu czy ze wspólnym korzystaniem z konkretnej sieci infrastruktury (transport, sieć gazowa i energetyczna, urządzenia wodno-kanalizacyjne). W skrajnych przypadkach efekt naśladownictwa może prowadzić do powstania złożonych struktur klastrowych.

Behawioralne czynniki lokalizacji w kontekście poznawczych i motywacyjnych skłonności inwestorów przedstawiono w tab. 2. Każdy z wyszczególnionych czynników można bowiem - zgodnie z założeniami ekonomii behawioralnej - odnieść do konkretnych efektów i różnych rodzajów heurystyki (Kahneman, 2011; Thaler, Sunstein, 2017; Zielonka, 2011).

Wybór miejsca usytuowania hotelu z wykorzystaniem własnej intuicji może się wiązać chociażby ze skłonnościami poznawczymi zdefiniowanymi jako nadmierny optymizm i heurystyka afektu. W pierwszym przypadku decydent może przesadnie ufać swojej intuicji i być nierealistycznie przekonany o dobrym wyborze lokalizacji hotelu. Ponadto zdarza się, że na podjętą decyzję ma również wpływ stan emocjonalny decydenta (heurystyka afektu), rzutujący na postrzeganie zjawisk, przez co potencjalna lokalizacja jest oceniana zarówno zbyt optymistycznie, jak

Tabela 2. Behawioralne czynniki lokalizacji a poznawcze i motywacyjne skłonności inwestorów

\begin{tabular}{|l|l|l|}
\hline \multicolumn{1}{|c|}{ Czynniki behawioralne } & \multicolumn{1}{|c|}{ Skłonności poznawcze } & \multicolumn{1}{|c|}{ Skłonności motywacyjne } \\
\hline Intuicja & $\begin{array}{l}\text {-nadmierny optymizm, } \\
\text { - heurystyka afektu. }\end{array}$ & $\begin{array}{l}\text { - torowanie afektywne, } \\
\text {-pułapka projekcji. }\end{array}$ \\
\hline Doświadczenie & $\begin{array}{l}\text {-nadmierna pewność własnej wiedzy i umiejętności, } \\
\text {-złudzenie kontroli, } \\
\text { - heurystyka dostępności. }\end{array}$ & $\begin{array}{l}\text { - awersja do strat, } \\
\text { - kołowrót szczęścia. }\end{array}$ \\
\hline Miejsce pochodzenia i zamieszkania & - efekt myślenia wstecznego, \\
& - dysonans poznawczy. & $\begin{array}{l}\text { - efekt posiadania, } \\
\text { - efekt status quo. }\end{array}$ \\
\hline Efekt naśladownictwa & $\begin{array}{l}\text { - pułapka potwierdzania, } \\
\text { - heurystyka zakotwiczenia, } \\
\text { - podstawowy błąd atrybucji, } \\
\text { - heurystyka reprezentatywności, } \\
\text { - dodatni i ujemny efekt świeżości. }\end{array}$ & $\begin{array}{l}\text { - księgowanie mentalne, } \\
\text { - efekt utopionych kosztów, } \\
\text { - hedoniczne kadrowanie, } \\
\text { - efekt dyspozycji, } \\
\text {-krótkowzroczne unikanie strat. }\end{array}$ \\
\hline
\end{tabular}

Źródło: opracowanie własne na podstawie: Kahneman (2011); Thaler, Sunstein (2017); Zielonka (2011). 
i zbyt pesymistycznie. Jedna - niekoniecznie kluczowa - cecha danego miejsca może $w$ tym przypadku zaważyć na opinii na jego temat, a co za tym idzie - przesądzić o wybraniu lub odrzuceniu go. Torowanie afektywne i pułapka projekcji to z kolei potencjalne skłonności motywacyjne przedsiębiorców kierujących się intuicją. Podejmowanie decyzji pod wpływem emocji może łączyć się z przywiązaniem decydenta do informacji wspierających jego stan emocjonalny oraz ignorowaniem tych, które są z nim sprzeczne. Osoba zadowolona będzie bardziej cenić optymistyczne wiadomości o danym miejscu, a niezadowolona - pesymistyczne. Torowanie afektywne może doprowadzić do wzmocnienia dobrego lub złego nastroju i utrzymania status quo lub do analizy problemów i zastanowienia się nad wprowadzeniem ewentualnych zmian. Decydent zdający się na własną intuicję i będący w określonym nastroju może wpaść w pułapkę projekcji, oczekując, że aktualny stan emocjonalny, a w ślad za nim ocena umiejscowienia hotelu nie zmienią się w przyszłości.

Osoby polegające na własnym doświadczeniu w procesie wybierania lokalizacji narażone są na nadmierną pewność w odniesieniu do własnej wiedzy i umiejętności. Ich przekonanie o poprawności własnych ocen i przecenianie swoich kompetencji może doprowadzić do podjęcia błędnej decyzji. Zjawisku temu towarzyszy często złudzenie kontroli, tj. przekonanie właściciela hotelu o możliwości wpływania na zjawiska, które tak naprawdę nie są od niego zależne (np. wielkość popytu turystycznego czy dostęp do pracy). Z wykorzystywaniem własnego doświadczenia wiąże się także heurystyka dostępności. Im decydent lepiej pamięta podjęte wcześniej decyzje biznesowe, czy nawet pozabiznesowe, tym bardziej prawdopodobne jest, że będzie przekonany o ich dużej wadze oraz o wystąpieniu w przyszłości podobnego zdarzenia (np. korzystnych warunków otoczenia makroekonomicznego). Ludzie są bardziej wrażliwi na straty niż na zyski (awersja strat), co powoduje, że nawet w przypadku przejściowych kłopotów finansowych decydenci opierający wybór umiejscowienia hotelu na doświadczeniu mogą zrezygnować z lokalizacji o dużym potencjale, która nie jest jeszcze zbyt popularna wśród innych przedsiębiorców. Należy jednak zaznaczyć, że osoby, którym się wiodło w ostatnim czasie, mogą wpaść w tzw. kołowrót szczęścia i wybierać nawet ryzykowne lokalizacje, tylko po to, aby sprostać rosnącym oczekiwaniom finansowym i sprawić, by zadowolenie z życia utrzymywało się cały czas na takim samym poziomie.

O efekcie myślenia wstecznego i wystąieniu stanu dysonansu poznawczego możemy mówić w odniesieniu do decydentów, dla których kluczowym czynnikiem lokalizacji będzie miejsce pochodzenia lub zamieszkania. Wiąże się to z przekonaniem osoby podejmującej decyzję, że można się było spodziewać nastąpienia zaistniałych zdarzeń i że były one o wiele bardziej prawdopodobne i łatwiejsze do przewidzenia niż zjawiska niewystępujące. Może tutaj wystąpić również dysonans poznawczy, a więc uczucie napięcia z powodu konfliktu między elementami poznawczymi. Niekiedy nasila się on ze względu na wzrost znaczenia danego elementu (np. wpływ wyboru miejsca, w którym ma zostać utworzony nowy obiekt, na sytuację finansową całej sieci hoteli), stopień sprzeczności między nimi (np. wybór lokalizacji oparty na miejscu pochodzenia, pomimo niezbyt dobrej sytuacji rynkowej na tym obszarze) czy niemożność pogodzenia ich ze sobą (np. groźba strat w hotelu w wybranej w ten sposób lokalizacji). Wskutek podjęcia decyzji ze względu na miejsce pochodzenia lub zamieszkania wzmocnieniu ulega efekt posiadania, gdyż decydent bardziej ceni dobra, którymi dysponuje i/lub o których dużo wie, od tych, których nie ma i/lub nie zna. Może to prowadzić do powstania efektu status quo, a więc pozostawania przy wyborze lokalizacji w miejscu swojego zamieszkania lub pochodzenia z powodu awersji do potencjalnych strat.

Największą liczbą zagrożeń, wynikających ze skłonności decydenta, niesie za sobą efekt naśladownictwa jako potencjalny czynnik umiejscowienia hoteli. Decydent może poszukiwać informacji lub interpretować napływające dane tak, aby uzyskać potwierdzenie, że wybrana $\mathrm{w}$ ten sposób lokalizacja obiektu jest dobra (pułapka potwierdzania). Wiązać się z tym może tzw. efekt zakotwiczenia, a więc powzięcie postanowienia na podstawie dostępnych $\mathrm{w}$ danym czasie, nawet przypadkowych informacji. Opieranie decyzji lokalizacyjnych na zachowaniach innych ludzi łączy się niekiedy z tendencją do przeceniania czynników osobowościowych i niedoceniania czynników sytuacyjnych w wyjaśnianiu postępowania tych osób (podstawowy błąd atrybucji). Często uzasadnieniem takiego wyboru jest również analiza pojedynczych przypadków, a nie większych, reprezentatywnych prób osób podejmujących tego rodzaju decyzje w przeszłości. Należy się również spodziewać, że najważniejsze dla decydentów będą decyzje podjęte $\mathrm{w}$ ostatnim czasie i prognozowanie przez nich utrzymania lub odwrócenia tendencji w zakresie sytuacji finansowej hoteli funkcjonujących już w tym miejscu. Poniesione przez inwestorów nakłady na ulokowanie hotelu w danym miejscu (np. poświęcony czas i zaangażowanie, koszty przejazdów, zakupu raportów, opłaty administracyjne itp.) mogą doprowadzić do wystąpienia zjawisk księgowania mentalnego i utopionych kosztów. Trudność lub brak możliwości odzyskania tych nakładów może wpłynąć na kontynuowanie procesu wyboru danej lokalizacji. Im większe, z perspektywy decydenta, środki zostały przez niego zainwestowane, tym większa będzie jego niechęć do rezygnacji nawet $\mathrm{z}$ ryzykownego projektu. W zależności od sytuacji nakłady te mogą być również sumowane lub rozdzielane (hedoniczne kadrowanie). Może pojawić 
się wówczas także efekt dyspozycji, polegający w opisanej sytuacji na tym, że decydent, zdając sobie sprawę z dużego ryzyka niepowodzenia przedsięwzięcia, nie będzie skłonny wycofać się z danej inwestycji. Osoby wykorzystujące efekt naśladownictwa mogą odczuwać również dyskomfort w przypadku podjęcia wstępnej decyzji lokalizacyjnej i obserwowania przejściowych kłopotów innych hoteli ulokowanych w tym miejscu (krótkowzroczne unikanie strat).

\section{METODYCZNE ZAŁOŻENIA BADAŃ}

W pracy wykorzystano cztery główne metody badawcze, takie jak: przegląd piśmiennictwa, metoda dokumentacyjna, sondażu diagnostycznego i przypadków indywidualnych. W ramach analizy literatury przygotowano spis książek i artykułów dotyczących problematyki behawioralnych aspektów lokalizacji. Wykorzystanie metody dokumentacyjnej (obserwacji pośredniej) związane było z pozyskaniem ze źródeł wtórnych, tj. z Głównego Urzędu Statystycznego (2019) oraz Ministerstwa Sportu i Turystyki w Warszawie (2019), danych niezbędnych do zidentyfikowania hoteli zlokalizowanych w województwie opolskim. Metoda sondażu diagnostycznego obejmowała wywiad pogłębiony, skategoryzowany, o charakterze jawnym. Narzędziem badawczym był kwestionariusz wywiadu skonstruowany przez autora dla potrzeb pracy badawczej, złożony z siedmiu pytań otwartych dotyczących wybranych aspektów lokalizacji oraz z metryczki. Respondentom podczas wywiadu zadano następujące pytania:

1. Czy proces wyboru lokalizacji był dla Państwa decyzją opartą na obiektywnych przesłankach?

Tabela 3. Charakterystyka organizacyjno-funkcjonalna analizowanych przedsiębiorstw hotelowych

\begin{tabular}{|c|c|c|c|}
\hline Kryterium & Cecha & Liczba & Odsetek \\
\hline \multirow{3}{*}{ Pochodzenie kapitału } & krajowy & 22 & 71,0 \\
\hline & zagraniczny & 1 & 3,2 \\
\hline & mieszany & 8 & 25,8 \\
\hline \multicolumn{2}{|l|}{ Razem } & 31 & 100,0 \\
\hline \multirow{4}{*}{ Wielkość przedsiębiorstwa } & mikro & 0 & 0,0 \\
\hline & małe & 19 & 61,3 \\
\hline & średnie & 12 & 38,7 \\
\hline & duże & 0 & 0,0 \\
\hline \multicolumn{2}{|l|}{ Razem } & 31 & 100,0 \\
\hline \multirow{4}{*}{ Forma prawno-organizacyjna } & przedsiębiorstwo własności indywidualnej & 15 & 48,4 \\
\hline & spółka cywilna & 4 & 12,9 \\
\hline & spółka jawna & 4 & 12,9 \\
\hline & spółka z o.o. & 8 & 25,8 \\
\hline \multicolumn{2}{|l|}{ Razem } & 31 & 100,0 \\
\hline \multirow{2}{*}{ Stopień integracji } & niezależny & 29 & 93,5 \\
\hline & zintegrowany & 2 & 6,5 \\
\hline \multicolumn{2}{|l|}{ Razem } & 31 & 100,0 \\
\hline \multirow{5}{*}{ Kategoria hotelu } & * & 2 & 6,5 \\
\hline & ** & 6 & 19,4 \\
\hline & $* * *$ & 19 & 61,2 \\
\hline & $* * * *$ & 4 & 12,9 \\
\hline & $* * * * *$ & 0 & 0,0 \\
\hline \multicolumn{2}{|l|}{ Razem } & 31 & 100,0 \\
\hline \multirow{4}{*}{ Główny produkt hotelu } & biznesowy & 17 & 54,6 \\
\hline & wypoczynkowy & 10 & 32,3 \\
\hline & tranzytowy & 2 & 6,5 \\
\hline & okolicznościowy & 2 & 6,5 \\
\hline \multicolumn{2}{|l|}{ Razem } & 31 & 100,0 \\
\hline
\end{tabular}

Źródło: opracowanie własne na podstawie wyników badań sondażowych. 
2. Czy obecne umiejscowienie hotelu było jedynym branym pod uwagę?

3. Czy mieli Państwo jakieś wcześniejsze doświadczenia w wyborze lokalizacji hoteli bądź innych rodzajów działalności gospodarczej?

4. Jakie czynniki były dla Państwa najważniejsze podczas ustalania, gdzie będzie się znajdował hotel?

5. Czy na Państwa decyzję lokalizacyjną wpłynęły działania stymulacyjne, podejmowane przez władze lokalne lub regionalne?

6. Jakiego rodzaju czynniki o charakterze behawioralnym brali Państwo pod uwagę w procesie wyboru lokalizacji?

7. W jaki sposób zbierali Państwo informacje przed powzięciem postanowienia o miejscu otworzenia hotelu? Przed przystąpieniem do badań zasadniczych kwestionariusz poddano testom pilotażowym i poprawiono w nim wszystkie dostrzeżone błędy. Biorąc pod uwage stan wiedzy na temat zasad prawidłowego przeprowadzenia badań bezpośrednich, polegających na zbieraniu danych ze źródeł pierwotnych, poinformowano wcześniej respondentów, jaki jest cel tych działań i jak one będą przebiegały. Dobór próby miał charakter celowy. W sondażu uwzględniono 31 hoteli, których właściciele wyrazili chęć udziału w badaniu, co stanowiło ok. $48 \%$ wszystkich obiektów hotelowych funkcjonujących na obszarze województwa opolskiego. Badanie sondażowe (zasadnicze) przeprowadzono $\mathrm{w}$ pierwszej połowie $2019 \mathrm{r}$.

Podczas przygotowywania artykułu wykorzystano również metodę indywidualnych przypadków. Wyniki badań sondażowych były bowiem podstawą do sformułowania zbiorowego studium przypadku opartego na najbardziej typowych sytuacjach związanych $z$ rozpatrywanymi przez decydentów behawioralnymi czynnikami lokalizacji.

Spośród hoteli branych pod uwagę $\mathrm{w}$ badaniach $71,0 \%$ było finansowanych z kapitału krajowego, 25,8\% - $\mathrm{z}$ mieszanego, a 3,2\% - z zagranicznego. Małe przedsiębiorstwa stanowiły $61,3 \%$ wszystkich badanych obiektów, a średnie - 38,7\%. Niemal połowa hoteli $(48,4 \%)$ prowadzona była jako przedsiębiorstwa własności indywidualnej, a 51,6\% jako spółki (najczęściej z ograniczoną odpowiedzialnością - $25,8 \%$, oraz cywilne i jawne - po 12,9\%). Analizując stopień integracji z innymi podmiotami gospodarczymi, dostrzeżono, że większość badanych obiektów $(93,5 \%)$ to hotele niezależne. Hoteli zintegrowanych było zaledwie 6,5\%. Ponad $60 \%$ obiektów skategoryzowanych zostało jako trzygwiazdkowe, a niemal $20 \%$-jako dwugwiazdkowe. Hoteli czterogwiazdkowych było $12,9 \%$, a jednogwiazdkowych $-6,5 \%$. W rozpatrywanej grupie przeważały obiekty biznesowe $(54,6 \%)$ i wypoczynkowe $(32,3 \%)$. Hoteli oferujących produkt tranzytowy i okolicznościowy było natomiast po 6,5\% (tab. 3).

\section{BEHAWIORALNE PRZESŁANKI WYBORU LOKALIZACJI HOTELI Z WOJEWÓDZTWA OPOLSKIEGO W ŚWIETLE BADAŃ EMPIRYCZNYCH}

Analiza wyników przeprowadzonych badań wykazała, że decydenci ok. połowy branych pod uwagę hoteli $(48,4 \%)$ nie podejmowali żadnych intencjonalnych, opartych na obiektywnych przesłankach działań zmierzających do wyboru miejsca lokalizacji swojego obiektu. Ponadto jedna trzecia respondentów $(32,2 \%)$ zadeklarowała, że stosowała wprawdzie obiektywne metody wyboru miejsca usytuowania hotelu, lecz komplementarnie uwzględniała także przesłanki natury subiektywnej. Niemal w co piątym rozpatrywanym obiekcie (19,4\%), w tym w dwóch badanych hotelach zintegrowanych, lokalizację ustalono natomiast na podstawie przesłanek obiektywnych (rys. 1).

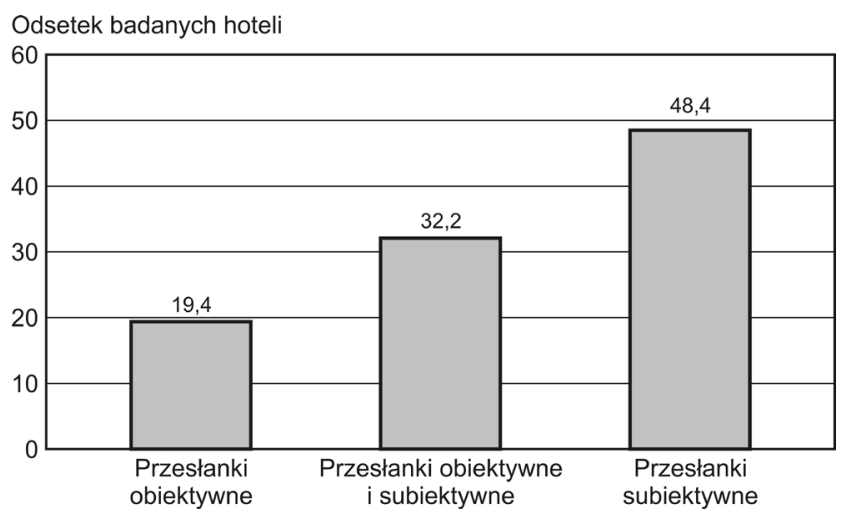

Rysunek 1. Przesłanki wyboru lokalizacji hoteli z województwa opolskiego

Źródło: opracowanie własne na podstawie wyników badań sondażowych

Wśród badanych reprezentujących podejście subiektywne można wyróżnić trzy typowe ścieżki, tj.:

- wybór lokalizacji wtórnej;

- wybór lokalizacji pierwotnej dokonany wyłącznie na podstawie analizy czynników behawioralnych;

- wybór lokalizacji pierwotnej dokonany na podstawie obiektywnych czynników lokalizacji, uzupełnionych o przesłanki behawioralne.

Wspólną cechą hoteli przypisanych do dwóch pierwszych ścieżek było to, że obecne miejsce ich usytuowania okazało się jedynym branym pod uwagę przez decydentów. Ponadto nie korzystali oni intencjonalnie z żadnych informacji dotyczących miejscowości, w której powstał hotel.

Wybór lokalizacji wtórnej, odnotowany w przypadku 36\% badanych właścicieli opowiadających się za subiektywnym podejściem, wiązał się często 
z rozbudową posiadanej wcześniej restauracji, w której wynajmowano kilka pokoi, oraz przekształceniem jej w hotel. Część obiektów powstała także na skutek zmiany koncepcji prowadzonej działalności gospodarczej. W konsekwencji obiekty hotelowe były tworzone w budynkach, w których wynajmowano wcześniej pomieszczenia biurowe lub mieszkania oraz prowadzono działalność związaną ze świadczeniem usług finansowych, w tym ubezpieczeniowych. W jednym przypadku właściciele hotelu mieli uprzednio dom wycieczkowy, który został gruntownie zmodernizowany i dostosowany do wymogów ustawowych. Wśród rozpatrywanych przypadków odnotowano także sytuację, w której osoby posiadające dwa zabytkowe budynki w centrum miasta, po odpowiednim dostosowaniu ich do wymogów, zaczęły świadczyć tam usługi hotelowe.

Zdarzało się, że respondenci byli wcześniej posiadaczami nieruchomości niezabudowanych, na których powstały później hotele. Niekiedy zakup działek ziemi został poczyniony wcześniej w celach inwestycyjnych. W czasach gdy ceny gruntów gwałtownie rosły, działka była swoistą inwestycją finansowa, gdyż wzniesiony na niej budynek miał być w przyszłości sprzedany z zyskiem. Spowolnienie gospodarcze i zahamowanie wzrostu cen nieruchomości spowodowały, że sprzedaż działek nie była już tak opłacalna i zdecydowano się na zmianę koncepcji biznesowej, w wyniku czego na posiadanej parceli wybudowano hotel.

W jednym analizowanym przypadku działkę ziemi nabyło przedsiębiorstwo, prowadzone w formie spółki. Celem zakupu była budowa budynku biurowego na wynajem. W międzyczasie ze spółki wycofał się jednak jeden ze wspólników i realizacja dotychczasowych zamierzeń inwestycyjnych, ze względu na niedobory kapitału, nie była możliwa. Zdecydowano się więc na zmianę przyszłego rodzaju działalności gospodarczej i zamiast planowanego wcześniej biurowca otworzono mały hotel.

W badaniu uwzględniono także przypadek właściciela, który był wcześniej posiadaczem działki ziemi, odziedziczonej po swoich rodzicach. Jej atrakcyjna lokalizacja sprawiła, że postanowił zbudować tam obiekt hotelowy.

Z kolei w odniesieniu do $24 \%$ obiektów wybór lokalizacji był dokonywany na podstawie analizy przesłanek subiektywnych. Proces ten wiązał się z koniecznością znalezienia odpowiedniej działki ziemi i stworzenia funkcjonalnej koncepcji hotelu. Podejmowane przez decydentów działania nie były jednak w pełni racjonalne, gdyż opierały się na czynnikach behawioralnych. O wyborze miejscowości, w których wybudowano później hotele, przesądzały takie aspekty, jak: miejsce pochodzenia lub zamieszkania, intuicja i spontaniczna decyzja przedsiębiorcy, a także przypadek, polegający na pojawieniu się okazji do nabycia gruntu w atrakcyjnym miejscu i w dobrej cenie. Jeden z decydentów przyznał, że nowy hotel otworzył za namową swoich dzieci. Oglądał działkę ziemi, która pierwotnie miała być przeznaczona na inne cele, lecz pod wpływem swojego potomstwa zdecydował się na zmianę koncepcji biznesowej. Ciekawym przypadkiem odnotowanym w badaniach była sytuacja, w której właścicielka hotelu niejako połączyła dwie opisywane ścieżki i podczas wyboru lokalizacji wtórnej uwzględniła głównie czynniki behawioralne. Wcześniej osoba ta prowadziła niewielki hotel w innym miejscu, lecz nie zaspokajał on w pełni popytu. Brak rezerwy lokalizacyjnej, wynikający z istnienia ścisłej zabudowy wokół ówczesnego obiektu, uniemożliwiał jednak jego rozbudowę. Właścicielka, kierując się sentymentem do miejsca, w którym prowadziła swoją dotychczasową działalność, nabyła znajdujący się w pobliżu duży budynek po byłym kinie i otworzyła w nim nowy hotel. Stara nieruchomość została natomiast wynajęta innemu podmiotowi gospodarczemu i przeznaczona na cele pozaturystyczne.

W ramach trzeciego zidentyfikowanego w badaniach podejścia, które wskazało $40 \%$ decydentów opierających się na przesłankach subiektywnych, wyboru lokalizacji pierwotnej dokonywano w sposób racjonalny, uwzględniając takie czynniki, jak: strumień popytu, dostępność komunikacyjna, bliskość dworca lub węzła komunikacyjnego, walory turystyczne (naturalne i kulturowe), centralne położenie, ograniczona konkurencja oraz niska cena gruntu. Ta grupa przedsiębiorców rozpatrywała przynajmniej dwie potencjalne lokalizacje hotelu, lecz dokładna analiza nie dała im pewności, gdzie powinni usytuować swój obiekt. Niepewność decyzyjna sprawiła, że postanowili skorzystać z trzech przesłanek behawioralnych. Respondenci postępujący w ten sposób w większości zadeklarowali, że odwołali się do własnej intuicji i dzięki niej dokonali wyboru. Niekiedy naśladowano także innych przedsiębiorców i uruchamiano nowy hotel w miejscowościach, w których funkcjonowały już dobrze prosperujące

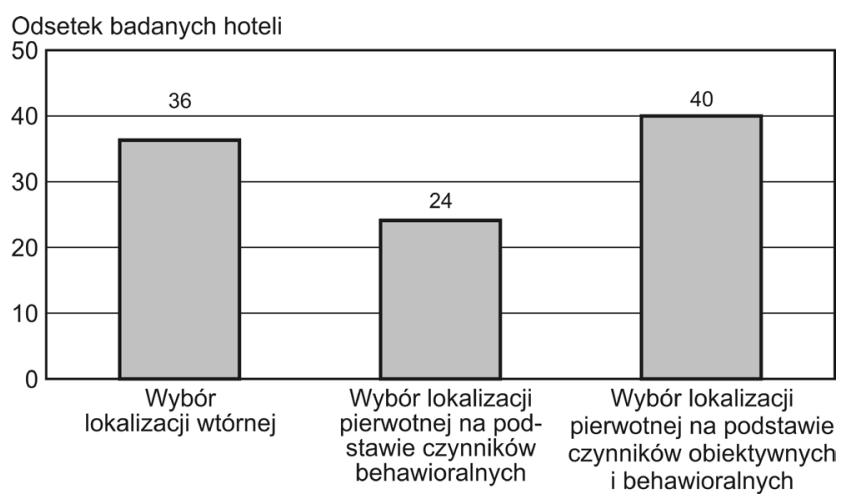

Rysunek 2. Ścieżki wyboru lokalizacji hoteli z województwa opolskiego

oparte na przesłankach subiektywnych

Źródło: opracowanie własne na podstawie wyników badań sondażowych 
obiekty tego rodzaju. W jednym przypadku głównym czynnikiem umiejscowienia nowego hotelu było doświadczenie życiowe decydenta. Wcześniej prowadził on bowiem restaurację usytuowaną w innej lokalizacji, którą wybrał samodzielnie. Również w tym przypadku dokonał samodzielnego wyboru, opierając się na własnym przekonaniu o dużych szansach na sukces biznesowy hotelu otworzonego w tym miejscu (rys. 2).

\section{ZAKOŃCZENIE}

Uzyskane wyniki badań potwierdziły znaczenie aspektów behawioralnych $\mathrm{w}$ procesie umiejscowienia hoteli niezależnych $\mathrm{w}$ województwie opolskim. Decyzja ta wiązała się zarówno z wyborem lokalizacji wtórnej, jak i pierwotnej. W drugim z wymienionych przypadków, gdy podejście obiektywne skutkowało brakiem pewności decyzyjnej, czynniki behawioralne odgrywały kluczową rolę $\mathrm{w}$ procesie decyzyjnym lub stanowiły jego uzupełnienie. Zatem również w takiej sytuacji wskazana grupa czynników miała kluczowe znaczenie, przesądzające o ostatecznym usytuowaniu hotelu.

Autor ma świadomość, że przedstawiona praca ma swoje mocne i słabe strony. Do mocnych stron artykułu należy przede wszystkim innowacyjna problematyka badań, gdyż znaczenie behawioralnych czynników lokalizacji hoteli nie było wcześniej weryfikowane empirycznie. Słabą stroną artykułu jest ograniczony zakres przestrzenny badań oraz zastosowanie wyłącznie metod o charakterze jakościowym.

Niejako na marginesie przeprowadzonych badań pojawiły się liczne wątki, które powinny, zdaniem autora pracy, stać się przedmiotem dalszych rozważań nad poruszaną problematyką:

1. Zakres przestrzenny zrealizowanych badań, obejmujący województwo opolskie, uprawnia jedynie do pewnych przypuszczeń dotyczących całego rynku hotelowego. Aby je zweryfikować, należy przeprowadzić pełne badania obejmujące obszar całej Polski, a nawet Europy Środkowo-Wschodniej.

2. W celu zwiększenia wiarygodności w kolejnych badaniach należy zastosować triangulację podejść metodologicznych, która powinna obejmować dane (pozyskane z różnych źródeł), metody (łączenie metod i technik ilościowych oraz jakościowych), analizy danych (zastosowanie kilku sposobów analizy statystycznej) oraz otoczenia (lokalizacja hoteli w różnych krajach i regionach).

3. Przegląd i krytyczna analiza piśmiennictwa wskazuja, że brakuje kompleksowych badań dotyczących lokalizacji, obejmujących zarówno jej aspekt ogólny (kraj, region, gmina), jak i szczegółowy (konkretna działka ziemi).
4. Za ważne należy uznać również badania dotyczące przesłanek lokalizacji przedsiębiorstw turystycznych innych niż hotelowe, ze szczególnym uwzględnieniem pozostałych podmiotów hotelarskich, biur podróży, atrakcji turystycznych, centrów rekreacji itp.

\section{BIBLIOGRAFIA}

Albert Tóth, A., Rechnitzer, J. (2018). Choice of location in the hotel industry. Tér és Társadalom, 32 (3), 128-142. DOI: https:// doi.org/10.17649/TET.32.3.3054

Alexander, N., Lockwood, A. (1996). Internationalization: A comparison of the hotel and retail sectors. The Service Industries Journal, 16 (4), 458-473. DOI: https://doi.org/10.1080/02642069600000041

Budner, W. (2004). Lokalizacja przedsiębiorstw. Aspekty ekonomiczne, przestrzenne i środowiskowe. Poznań: Wydawnictwo Akademii Ekonomicznej w Poznaniu.

Butler, R. (1980). The concept of a tourist area cycle of evolution: Implications for management of resources. The Canadian Geographer, 24 (1), 5-12. DOI: https://doi. org/10.1111/j.1541-0064.1980.tb00970.x

Cheng, S. (2018). Autocratic multi attribute group decision making for hotel location selection based on interval-valued intuitionistic fuzzy sets. Information Sciences, 427, 77-87. DOI: https://doi.org/10.1016/j.ins.2017.10.018

Chou, T., Hsu, C., Chen, M. (2008). A fuzzy multi-criteria decision model for international tourist hotel's location selection. International Journal of Hospitality Management, 27 (2), 293-301. DOI: https://doi.org/10.1016/j.ijhm.2007.07.029

Christaller, W. (1964). Some considerations of tourism location in Europe: The peripheral regions underdeveloped countries - recreations areas. Papers, Regional Science Association, 12 (2), 95-105. DOI: https://doi.org/10.1007/BF01941243

Damborsky, M., Wokoun, R. (2010). Location factors of small and medium entrepreneurship under the economic conditions of the Czech Republic. E\&M Ekonomie a Management, 13 (2), 32-43.

Główny Urząd Statystyczny (2019). Pobrane z: www.stat.gov.pl (7.06.2019).

Godlewska, H. (2005). Lokalizacja działalności gospodarczej. Warszawa: Wyższa Szkoła Menedżerska w Warszawie.

Griffin, D., Tversky, A. (1992). The weighing of evidence and the determinants of confidence. Cognitive Psychology, 24 (3), 411-435. DOI: https://doi.org/10.1016/0010-0285(92)90013-R

Hotelling, H. (1929). Stability in competition. Economic Journal, 39 (1), 41-57. DOI: https://doi.org/10.2307/2224214

Ju, P., Zhang, H., Wang, J. (2018). A projection-based outranking method with multi-hesitant fuzzy linguistic term sets for hotel location selection. Cognitive Computation, 10, 737-751. DOI: https://doi.org/10.1007/s12559-018-9552-2

Kahneman, D. (2011). Pułapki myślenia. O myśleniu szybkim i wolnym. Warszawa: Media Rodzina.

Kowalczyk, A. (2001). Geografia hotelarstwa. Łódź: Wydawnictwo Uniwersytetu Łódzkiego.

Kuciński, K. (2009). Geografia ekonomiczna. Kraków: Oficyna Wolters Kluwer Business.

Kundu, S., Contractor, F. (1999). Country location choices of service multinationals: An empirical study of the international hotel sector. Journal of International Management, 4, 299-317. DOI: https://doi.org/10.1016/S1075-4253(99)00017-4

Leśniewska-Napierała, K., Napierała, T. (2017). Funkcja hotelarska w rewitalizacji obszarów wiejskich. Studium przypadków 
w województwie pomorskim. Turyzm/Tourism, 27 (2), 65-76. DOI: https://doi.org/10.18778/0867-5856.27.2.06

Mariotti, S., Mutinelli, M., Piscitello, L. (2008). The internationalization of production by Italian industrial districts' firms: Structural and behavioural determinants. Regional Studies, 42 (5), 719-735. DOI: https://doi.org/10.1080/00343400701543264

Matczak, A. (2017). Zmiany w liczbie i pojemności hoteli w Polsce. Turyzm/Tourism, 27 (2), 77-87. DOI: https://doi. org/10.18778/0867-5856.27.2.07

Ministerstwo Sportu i Turystyki (2019). Pobrane z: www.msit. gov.pl (12.06.2019).

Miossec, J. (1977). Un modele de lespace touristique. L'Espace Géographique, 6 (1), 41-48. DOI: https://doi.org/10.3406/ spgeo.1977.1690

Popovic, G., Stanujkic, D., Brzakovic, M., Karabasevic, D. (2019). A multiple-criteria decision-making model for the selection of a hotel location. Land Use Policy, 84, 49-58. DOI: https://doi. org/10.1016/j.landusepol.2019.03.001

Puciato, D. (2015). Przestanki lokalizacji hoteli w Polsce. Praca doktorska. Warszawa: SGH.

Puciato, D. (2016). Attractiveness of municipalities in SouthWestern Poland as determinants for hotel chain investments. Tourism Management, 57, 245-255, DOI: https://doi.org/ 10.1016/j.tourman.2016.06.019

Puciato, D., Dziedzic, E. (2017). The attractiveness of the municipalities of the south-western Polish for hotel investors. Tourism Economics, 23 (3), 702-711. DOI: https://doi.org/ 10.5367/te.2016.0539

Puciato, D., Gawlik, A., Goranczewski, B. (2016). The origin of capital as a factor influencing location of new hotels on the example of Poland. International Journal of Contemporary Management, 15 (4), 31-55. DOI: https://doi.org/10.4467/2449 8939IJCM.16.023.6704

Puciato, D., Gawlik, A., Goranczewski, B., Oleśniewicz, P., Woś, B., Jandová, S., Markiewicz-Patkowska, J., Sołtysik, M. (2017). The factors influencing the decision on the location of hotels depending on their size in Poland. EEM Ekonomie a Management, 20 (2), 216-225. DOI: https://doi.org/10.15240/ tul/001/2017-2-016

Puciato, D., Oleśniewicz, P., Gawlik, A., Markiewicz-Patkowska, J., Widawski, K., Słaby, T., Kasprzak, R., Mróz-Gorgoń, B. (2019). Location factors for budget, medium standard and luxury hotels based on the example of hotels operating in Poland.
Operation Research and Decisions, 29 (1), 61-73. DOI: https://doi. org/10.5277/ord190104

Ren, L., Qiu, H., Ma, C., Lin, P. (2018). Investigating accommodation experience in budget hotels. International Journal of Contemporary Hospitality Management, 30 (7), 2662-2679. DOI: https://doi.org/10.1108/IJCHM-11-2016-0625

Romero-Martinez, A., Garcia-Muina, F., Chidlow, A., Larimo, J. (2019). Formal and informal institutional differences between home and host country and location choice: Evidence from the Spanish Hotel Industry. Management International Review, 59 (1), 41-65. DOI: https://doi.org/10.1007/s11575-018-0369-8

Thaler, R., Sunstein, C. (2017). Impuls. Jak podejmować właściwe decyzje dotyczace zdrowia, dobrobytu i szczęścia. Warszawa: Wydawnictwo Zysk i Spółka.

Townroe, P. (1972). Some behavioural considerations in the industrial location decision. Regional Studies, 6 (3), 261-272. DOI: https://doi.org/10.1080/09595237200185221

Ussi, M., Wei, J. (2011). The location determinants for hotel foreign direct investment in Zanzibar. Management and Service Science, 8, 105-112.

Włodarczyk, B. (2017). Hotele w przestrzeni miejskiej Łodzi. Turyzm/Tourism, 25 (2), 63-76.

Yang, Y., Wong, K., Wang, T. (2012). How do hotels choose their location? Evidence from hotels Beijing. International Journal of Hospitality Management, 31 (3), 675-685. DOI: https://doi. org/10.1016/j.ijhm.2011.09.003

Zhank, H., Guillet, B., Gao, W. (2012). What determines multinational hotel groups' locational investment choice in China. Hospitality Management, 31 (2), 350-359. DOI: https://doi. org/10.1016/j.ijhm.2011.05.008

Zielonka, P. (2011). Giełda i psychologia. Behawioralne aspekty inwestowania na rynku papierów wartościowych. Warszawa: CeDeWu.

Żakowska, S., Podhorodecka, K. (2018). Rozmieszczenie walorów turystycznych a lokalizacja noclegowej bazy turystycznej w województwie łódzkim. Turyzm/Tourism, 28 (2), 79-91, DOI: https://doi.org/10.18778/0867-5856.28.2.09

Artykuł wpłyną: 15 sierpnia $2019 \mathrm{r}$. Zaakceptowano do druku: 18 czerwca $2020 \mathrm{r}$. 